\title{
A Structuralist and Institutionalist developmental assessment of and reaction to New Developmentalism
}

\author{
Carlos Aguiar de Medeiros* \\ Full Professor, Economic Institute of UFRJ, Rio de Janeiro, Brazil
}

This paper provides a critical assessment of the New Developmental view summarized in Bresser-Pereira (2016). It is argued that although New Developmentalism correctly observes that Classical Developmentalism underestimated and insufficiently considered the role of demand as a motor of growth (this critique also applies to modern Schumpeterian views), New Developmentalism theoretically reduces or explains changes in quantities (in particular external demand) to the price mechanism (in particular the exchange rate). It is argued that the New Developmental narrative of comparative development underestimates the role of industrial policy and domestic demand in increasing productivity. Instead, New Developmentalism makes the real exchange rate the main lever for investment, structural change, and productivity growth. At the same time, New Developmentalism's description of some development trajectories is actually (though it is unacknowledged) closer to Classical Developmentalism, modern Institutionalism, and Schumpeterian thinking. Those intellectual traditions argue that development and structural change require strategic policies which go far beyond managing macroeconomic prices.

Keywords: Developmentalism, economic growth, economic policies, exchange rate, income distribution, East Asian countries, Latin American countries

JEL codes: $O 1, O 11, O 14, O 24, O 25$

\section{INTRODUCTION}

The comparative long-run economic performance of Latin American and East Asian economies is the source of great controversy in development economics and development policy. For the World Bank and Neoclassical economists, successful economic trajectories (mostly in Asia) are the result of high levels of saving, free trade, enabling market institutions, huge investment in human capital, and prudent macroeconomic interventions. That view is contested by the Economic Commission for Latin America and the Caribbean (ECLAC), the United Nations Conference on Trade and Development (UNCTAD), and heterodox economists who depart from a wider theoretical perspective (Classical, Marxian, Keynesian, and Schumpeterian). For these critics, a high rate of investment, export success, structural change, and technological innovation are

* This research received financial support from CNPQ. I would like to thank Franklin Serrano for his comments. This work is based on Medeiros (2017). 
all common features of high-growth economies. Achieving high growth requires strategic trade, capital controls, and developmental macroeconomics, as evidenced by the fact that all these policies were present in all successful development stories. These heterodox perspectives provide substantial criticism of mainstream development economics. They also provide useful insights regarding national development trajectories, economic growth, and the role of exports, technological progress, and macroeconomic policies.

In the first decade of the twenty-first century, when the terms of trade strongly changed in favor of primary exports, many heterodox authors and organizations following New Developmentalism (ND) argued that the main divide distinguishing successful East Asian countries and China relative to other developing countries, mostly primary exporters, was price competitiveness of the manufacturing sector achieved through a competitive real exchange rate (RER). That argument is especially clear in Bresser-Pereira (2016), published in this journal.

A first critical analysis of that proposition could be econometric. That would involve testing the hypothesis that the main explanatory factor for the different performances between Asian and Latin American countries is the RER. That is not the approach adopted here, as there are already several comparative studies both supporting and rejecting this proposition (see Fiorito et al. 2014). These tests do not 'prove' anything because any trajectory of development includes multiple factors that support it. Successful trajectories have cohesive economic, social, and political characteristics that engender a cumulative dynamic which cannot be decomposed into singular elements. ND seems to adopt a monocausal explanation of this cumulative dynamic centered on the absolute level of the real exchange rate. As with any monocausal explanation, that underestimates the complexity of the economic system with its many interactions.

Instead, I will take another route. First, I will critically appraise the ND perspective (as expounded by Bresser-Pereira in his 2016 paper). Thereafter, I will compare and contrast it with Classical Developmentalism (CD), which is Bresser-Pereira's name for the older and broader Structuralist approach. I will argue that due its wider scope this second perspective is more open to incorporating modern heterodox perspectives (particularly Evolutionist and Institutionalist analyses of East Asian industrialization) than ND, and it also provides more insights for interpreting contemporaneous development divergences. In contrast, ND tends to focus narrowly on macroeconomics settings.

In particular, it is argued that although ND correctly observes that CD underestimated or insufficiently considered the role of demand as a motor of growth (a critique that applies equally to modern Schumpeterian analysis), ND explains changes in quantities (in particular external demand) by reference to prices (in particular the exchange rate). Moreover, in contrast with other Keynesian perspectives, ND underplays the impact of macroeconomic prices on income distribution and distributive conflict. In this regard, it shares with more conventional thinking a view that modern underdevelopment (in middle-income countries) is due to a particular market failure (that is, exchange-rate failure). That is the logic behind the claim that macroeconomic prices, in particular the exchange rate, must be right in order to induce the structural changes necessary for faster economic growth (Bresser-Pereira 2016). That contrasts with CD and modern Institutionalist and Schumpeterian perspectives. For the latter perspective, prices have great importance for distribution, resource allocation, and competitiveness. However, they consider that development and structural change require a complex set of industrial policies, investment coordination and developmental institutions that far exceed ND's focus on macroeconomic prices. 
Though I will explore its main flaws, this is a sympathetic and constructive critique of the ND approach insofar as I recognize the ND perspective has the same fundamental objectives pursued by the Classical authors of development - namely, the development of the national material base and the raising of the standard of living of the population. However, ND's emphasis on the RER as the main driver of industrialization underestimates the complex interaction of factors that are emphasized in older and modern Structuralist and Institutionalist approaches to development economics.

The paper develops the argument in the remaining four sections. Section 2 presents the main propositions of ND; Section 3 discusses the connections between exports and balance-of-payments crises; Section 4 argues that industrialization and export diversification historically and currently demand multiple instruments and not only a competitive exchange rate; and Section 5 concludes the paper.

\section{THE MAIN THESIS OF NEW DEVELOPMENTALISM}

Bresser-Pereira (2016) presents a broad analysis of ND - originally it was dubbed 'structuralist development macroeconomics' - seeking to contrast it with Classical Developmentalism (CD), Keynesian macroeconomics, and 'really existing' Developmentalism (or 'social-developmentalism' as he describes the growth model followed in Brazil during recent decades). In this didactic piece, he presents in summary form his central propositions on political economy, economic theory, and economic policy. Although Bresser-Pereira seeks to situate ND in the same field as CD (including both the 'Development Pioneers' of the 1950s and 1960s ${ }^{1}$ and the Institutionalist interpreters of Asian industrialization ${ }^{2}$ ), he does not examine the broad themes discussed by those perspectives regarding economic development. The main theoretical contribution of ND concerns its macroeconomics. In addition to criticizing Neoclassical macroeconomics and the reforms proposed in the Washington Consensus thesis, ND claims to provide a critique of the macroeconomics endorsed by $\mathrm{CD}$, and especially of socialdevelopmentalism which according to Bresser-Pereira (2016) follows vulgar Keynesianism or populist Developmentalism.

According to him, the main differences between the ND approach and the CD approach (or Keynesian macroeconomics) are illustrated in four topics:

(i) the fundamental variables it uses are not the public deficit and the interest rate, but the current-account deficit and the exchange rate; (ii) what distinguishes developing economies from rich economies is no longer a social duality and a poorly structured market, but the fact that the former become indebted in foreign currency and are subject to balance-of-payment crises, whereas the latter become indebted in their own currency and are subject only to banking crises; (iii) contrarily to Keynesian macroeconomics, the existence of demand does not ensure investment and full employment, it is additionally required that the exchange rate assures access to demand, something that is not ensured due to the fact that the exchange rate may be overvalued in the long term; (iv) contrarily to what one assumes in classical developmentalism, developing countries don't need the capital of rich countries, in so far as (a) when they neutralize the Dutch disease, they will necessarily present a current-account surplus, and (b) foreign savings usually don't add to domestic savings and increase investment, but, rather, increase consumption. (Bresser-Pereira 2016, p. 335)

1. These pioneers include Raul Prebisch, Hans Singer, Rosenstein-Rodan, Ragnar Nurkse, Albert Hirschman, and Celso Furtado.

2. Institutionalist interpreters include Alice Amsden (1989; 2001), Robert Wade (1990), and Ha-Joon Chang (2006). 
The centrality of the current-account deficit as the main constraint on economic growth and the proposition that the external debt is the main reason for recurrent balance-ofpayments (BoP) crises are not a distinguishing feature of ND. They form a core concern of Raul Prebisch (1949), one of CD's leading thinkers. What is really new, and this is the main point ND claims, is the argument that the exchange rate is the fundamental variable which explains both the low rate of investment - by precluding business access to (external) demand - and the recurrent crises of the BoP. Thus for ND the recurrent crisis and low growth observed in most developing countries is due to wrong prices or prices that are inadequate for manufacturing investment. The tendency of the RER to overvaluation generated by the Dutch Disease is conceptualized as a market failure. According to Bresser-Pereira, when this market failure is neutralized in developing countries they necessarily run current-account surpluses.

Thus, although ND claims to be a modern theory of economic development it is essentially a 'developmental macroeconomics.' Bresser-Pereira summarizes 70 topics/items that constitute the main ND thesis, yet they do not include the central themes that define Classical and modern Developmentalism - such as technical progress, industrial policy, agriculture productivity, income distribution, investment in infrastructure, and coordination of investments through the state and the innovation system. Those structural themes are either not present at all or they appear only in a subsidiary way in developmental macroeconomics.

One might counter that some of these central themes of $\mathrm{CD}$ are historically dated and refer to the implanting of industries in pre-industrial agrarian economies, whereas middle-income countries (hereafter MICs) face different problems which are mainly macroeconomic and which ND tries to address. Additionally, one might argue that for the most part these developmental themes can be accommodated within and are compatible with the theoretical and analytical macroeconomic framework proposed by ND. In this critical essay, I consider both arguments and find them unconvincing. It is not convincing to view ND as just an update of $\mathrm{CD}$, and nor is it convincing to view ND as just providing a macroeconomics that complements the other propositions of CD.

Although ND offers an alternative perspective to the Washington Consensus and conventional development macroeconomics, it makes startling new claims that the only technological and institutional challenge that developing countries face today is excessive competition of labor-intensive industrial production. ND disregards the systemic vision of $\mathrm{CD}$, while its growth strategy predicated on exports disregards the 'fallacy of composition' problem. That reflects its perspective of 'methodological nationalism' whereby each country is treated as an isolated unit.

It is appropriate to examine some main themes examined by development economics and contrast them with ND. Table 1 presents a selective summary of the main perspectives.

As can be seen from the synthesis shown in Table 1, contemporary Neoclassical and non-Neoclassical (Keynesian, Schumpeterian) interpretations are also concerned with many of the same issues as CD. In a technological asymmetrical and polarized world in which specialization in commodities versus manufacturing no longer exhaustively defines the dichotomy of 'center-periphery,' the main challenge for developing countries seeking sustained growth is to induce a broad process of technological change that delivers production with higher technological content, higher employment, and higher wages.

Dynamic economies of scale, uncertainty, and technological backwardness require coordination of investment, long-term technological thinking, and a national system of 


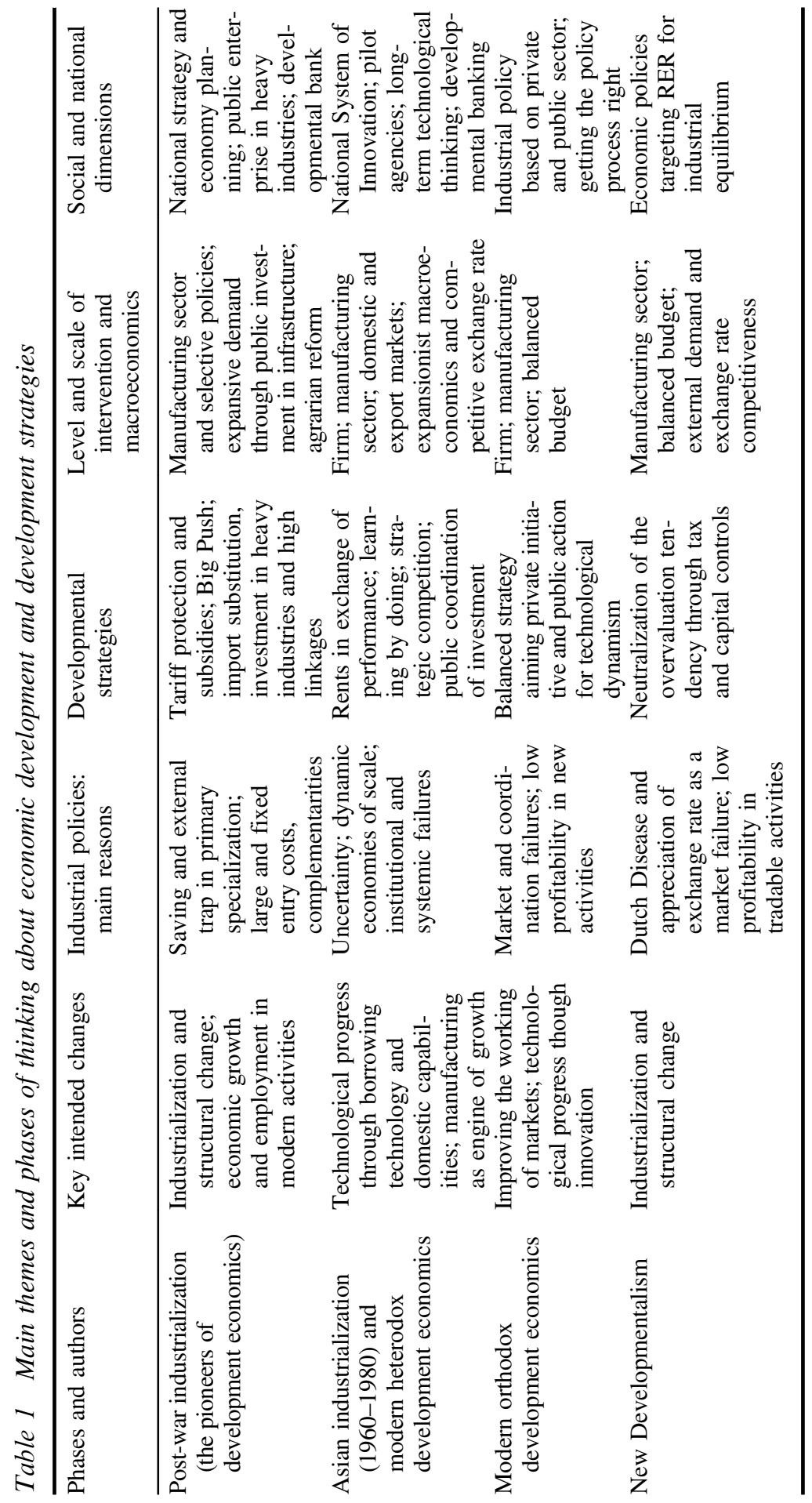


innovation (NSI). However, ND assumes that companies in MICs are already connected to external markets and that they already possess updated technology, infrastructure, and modern institutions for competition. The only problem is market failure regarding determination of the equilibrium RER (a feature that Japan, South Korea, and Taiwan did not have, according to Bresser-Pereira). ND supposedly adopts a heterodox perspective on macroeconomics, yet it adheres to an 'imperfectionist thesis' (Medeiros and Serrano 2004) that only makes sense in Neoclassical economics. Several modern Developmentalist authors close to mainstream economics (for example, Rodrik 2004; Hausman and Hidalgo 2010) argue for policies and interventions in developing countries aimed at solving market failures in information, innovation, and investment coordination. Bresser-Pereira (2016) adds the exchange rate to the list of market failures that obstruct development.

Bresser-Pereira (2016) is right when he criticizes CD for underestimating or even ignoring the importance of demand for growth. ${ }^{3}$ However, he seems to assume that effective demand (a quantity) responds directly and meaningfully to change in prices. Consequently there is always demand for manufacturing production if the exchange rate and the profit rate are appropriate. ${ }^{4}$ The role of real wages and other sources of domestic demand are implicitly subsidiary (and subject to BoP restrictions) because external markets provide demand for manufactures.

The ND perspective contrasts with several contemporary Developmentalist and Institutionalist authors (for example, Alice Amsden, Robert Wade, Ha-Joon Chang), and more recently Mariana Mazzucato (2013), who highlight the complementarity of internal and external markets and also consider the internal market to be an essential dimension for external competitiveness. As I argue in the next section, domestic demand is the major source of manufacturing demand for most developing countries.

Although Bresser-Pereira's summary of the central theses of ND contains 70 topics/ items, the determination of the exchange rate and its importance for the understanding of the developmental trajectories is the dominant theme in almost all the propositions. That reductionism of the development challenges to wrong determination of macroeconomic prices is shown in Table 2 (pp. 154-155), which provides a brief synthesis of Bresser-Pereira's (2016) summary of ND and also makes some critical assessments based on the central propositions of Classical and modern Developmental (CMD) theory. Some of these critical assessments are further addressed in the next sections.

\section{EXPORTS AND BALANCE-OF-PAYMENTS CRISES}

ND favors export-led growth 'up to the moment when low wages represent a competitive advantage in relation to rich countries' (Bresser-Pereira 2016, p. 347). Although this proposition is a theoretical hypothesis, if ND is correct it should also conform with the historical experience of East Asian countries which inspire ND thinking. Moreover, it should also be possible for all developing countries to pursue.

ND may misunderstand the role of exports by viewing them exclusively as the main component of autonomous demand in a country (be it developed or developing), when their real significance is as a source of foreign exchange which is essential for a

3. For a discussion of the influence of Say's law in Developmentalism, see Medeiros and Serrano (2004).

4. For further discussion, see Amico and Fiorito (2017). 
country's capacity to import. That argument was made by Kaldor $(1966 ; 1978 b)$ in his consideration of the role of exports in modern economic growth.

Consequently, exports can play two different roles. In some countries, exports may constitute the predominant source of final demand, and industrial production grows according to the growth of their external markets. That was the case in nineteenthcentury Britain (examined by Kaldor 1966), but it was not the case in the US. Among peripheral countries, exports of primary goods engendered a pattern of outward development - 'desarrollo hacia fuera' as termed by ECLAC's economists or export-led growth, typical of Latin American countries during the nineteenth century and still very much the case in many Latin American and African mineralor energy-rich countries. The final demand role of exports was also central to the post-World War II growth of the Asian Tigers (South Korea, Taiwan, Hong Kong, and Singapore) which focused on exports of manufactures. It was also critical in East Asian economies in which there were large investments by multinational companies in export processing areas (for example, Malaysia and Thailand). However, in other Asian countries such as China and India and other large developing economies in Latin America, the most important role of exports is to finance their imports needs and other currency expenses and thereby permit a higher rate of growth. That does not make their growth regimes export-led even though exports are critical, and the growth regime actually relies on domestic demand.

In macroeconomics it is standard practice to search for statistical confirmation (for example, correlations and econometric tests) of theoretical claims. However, in development macroeconomics, if not accompanied by historical analysis, this can lead to the flaw of 'methodological nationalism' (Gore 1996), whereby countries are assumed to be abstract entities, economies are open but not situated in specific international contexts, and the observed performance between economies is fully explained by domestic policies. Methodological nationalism treats nation states as if they were rational individuals with preferences and internal factors are exclusively domestic policies. ${ }^{5}$ An unavoidable consequence of this perspective is the tendency to a normative approach whereby history supposedly provides 'lessons' that can be replicated. ND partakes of such methodological nationalism owing to its lack of concern with either geopolitics or class struggle. Both of those factors were important in the explanation of East Asian industrialization and export-led growth. Macroeconomic or developmental features observed in comparative studies cannot be fully explained just by reference to decisions taken within countries. Outcomes are influenced by specific and unique circumstances so that economic policy decisions, institutions, and instruments do not produce the same effects across countries.

Japan, South Korea, Taiwan, and Singapore do not have large natural resource endowments, including energy (the same holds for China in recent years, with a very low land-population ratio). Consequently, technological modernization was not possible without strong growth in industrial exports. Manufacturing exports was not a choice of economic policy, but rather an imposition of this material reality - or, as Amsden (1989) remarked regarding Korea, it was a compulsion.

The combination of low labor costs in dollars, modern technology in light industries, and access to the American market was a common feature that historically distinguished the starting point and initial export drive of these East Asian countries.

5. The Washington Consensus is a globalizing normative liberalism (that is, the liberal order is superior), but it is also methodologically nationalist in that correct prices and domestic economic fundamentals explain everything. 
154 Review of Keynesian Economics, Vol. 8 No. 2

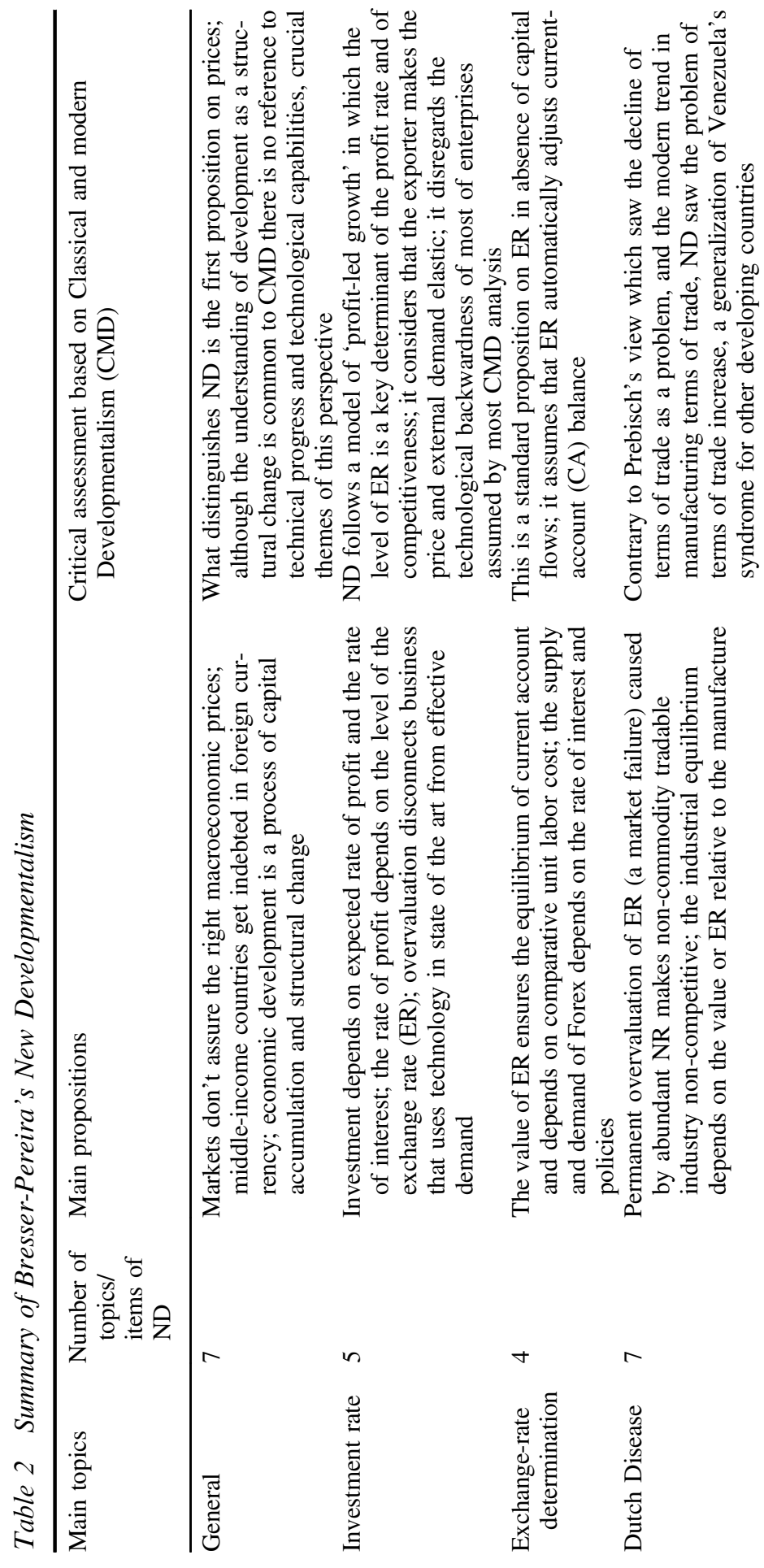



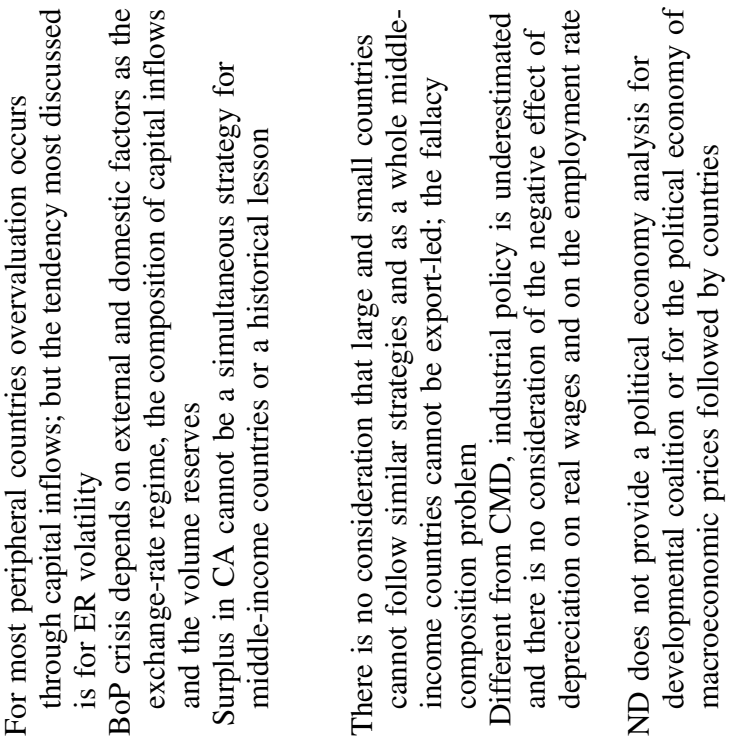

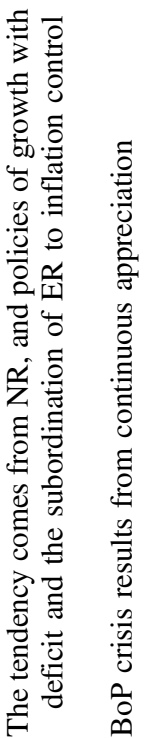

Ð

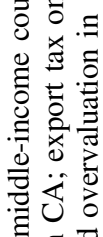

.

bi

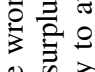

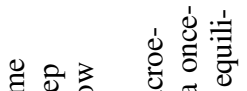

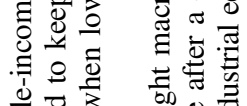

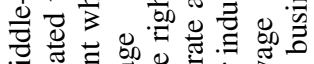

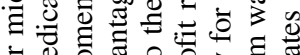

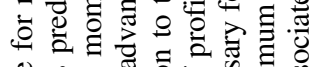

ษ.:

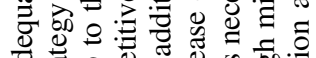

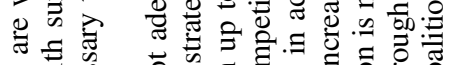

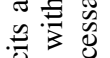

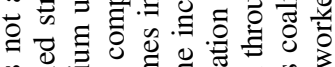

递密

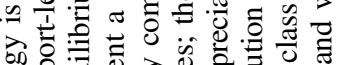

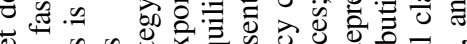

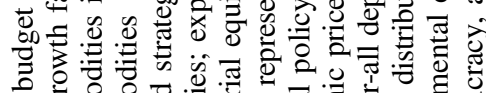

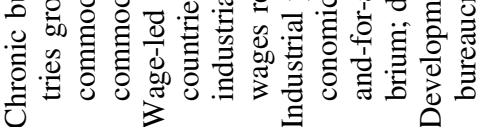
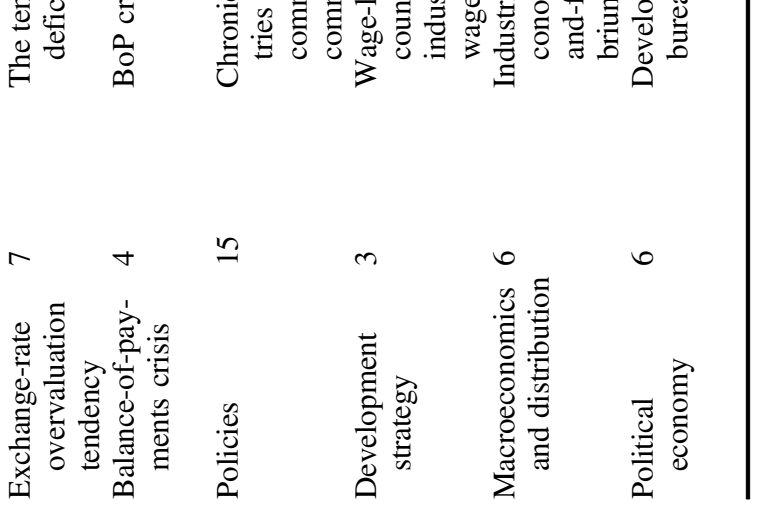
That combination was partly a consequence of their structure and post-war geopolitics. Countries with other structures and other geopolitical insertions, such as India or Pakistan, did not become major textiles exporters despite low wages, abundance of labor, and competitive change.

Those special countries where exports represent a high share of GDP benefit from multiplier and accelerator effects induced by export-led GDP growth. However, most developed and developing countries (Asian or Latin America) have the domestic markets as their major market for manufacturing production. This was true in the 1960s and 1970s, and it is true today, particularly after the 2008 financial crisis (Palley 2012; UNIDO 2017). In countries where domestic demand comprises a higher share of GDP, the rate of GDP growth depends on the evolution of government spending and private consumption, particularly financed though wages and credit. Empirical evidence (UNIDO 2017) shows that domestic demand is the predominant market for manufacturing in most developing countries. ${ }^{6}$ The most important drivers, according to the UNIDO (2017) survey, have been the evolution of real wages, the expansion of the middle classes, and consumption diversification. In conjunction with public consumption, household consumption constitutes the main demand impulse for private investment (Cesaratto et al. 2003). In China and Japan, the autonomous components of domestic demand have historically predominated in the total demand. It was affirmed that Korea and Taiwan pursued an 'export-led' regime of growth, yet economic policies have also always sought high growth with flexibility vis-à-vis the economic cycle.

That experience was very different from Asian countries such as Malaysia, Thailand, Indonesia, and the Philippines, as well as for Mexico (after NAFTA), where growth has been export-led through devalued exchange rates and integration into the global value chains led by transnational corporations. What made the East Asian strategy successful was not a devalued exchange rate, but its combination with a broad industrial policy (see the next section).

Independently of the growth regime, the rate of GDP growth is conditioned by the BoP. Countries that do not issue reserve currency cannot finance chronic BoP disequilibrium. Thus, as argued by Thirlwall (1979), they cannot grow at a sustainable rate higher than the rate given by the ratio of the rate of export growth and the income elasticity of imports. This ratio is influenced by structural and technological factors and cannot be raised through low wages expressed in international currency terms.

Exports of goods and services and short- and long-term capital inflows play different roles with regard to the BoP constraint. Export growth was important during periods when capital inflows were scarce (as occurred in 1950s, 1960s, and 1980s), as well as during periods when there was capital outflow from developed economies (in the 1970s, and from the 1990s until today). However, high export growth may not be enough to sustain high output growth and preclude the emergence of financial vulnerability as unregulated capital flows are an independent source of BoP crises (Medeiros 2008a).

Most analyses of BoP constraints and the external gap problem consider financial fragility an unavoidable consequence of exchange-rate appreciation. Bresser-Pereira (2016, p. 344) argues that, as a 'consequence of this tendency ... developing countries

6. 'For at least 25 years, domestic absorption has driven final demand for manufacturing, both at world level and across countries at different stages of industrial development' (UNIDO 2017, p. 66). 
will go from one currency or BOP crisis to another.' Amsden (2001) adopts a different perspective that also stresses real-economy problems resulting from overexpansion and resulting current-account deficits. The history of BoP crises in developing countries since the nineteenth century shows that overborrowing and overlending by bankers have played an autonomous role in the rapid deterioration of external solvency. To keep the solvency rate (current-account deficit/exports) and liquidity rate (short-term capital inflows/reserves) manageable, control of the capital account and flexibility of the exchange regime are of the utmost importance. ND fully accepts this autonomous source of financial instability (explained exclusively by wrong domestic policies in setting the interest rate in a deregulated financial market), but the transmission mechanism into the real economy is underarticulated and relies essentially on overvaluation of the exchange rate.

Since World War II, the world economy has experienced three strong boom-bust financial cycles, which occurred in the 1970s, the 1990s, and the first decade of the twenty-first century. In the 1970s, capital controls (financial repression in orthodox jargon) were widely present but this did not prevent the generation of high external debt in the majority of developing countries - particularly Argentina, Brazil, and Mexico in Latin America, and South Korea in Asia. These debt problems arose independently of how countries used the capital inflows (that is, for furthering import substitution, for export diversification, or even for domestic consumption). During the 1990s financial liberalization eliminated capital controls in several developing countries but not in China, India, or Taiwan. That promoted a large increase in external debt and other short-term liabilities, resulting in deep BoP crises in East Asia (but not China, India, or Taiwan), and in Latin America. In the last financial cycle that ended in 2008, capital controls were back through tax and prudential measures, but this still did not prevent large amounts of capital inflows. However, in contrast with the 1990s, no comparable financial crisis occurred in the developing countries.

In these financial cycles, the RER followed a boom-bust pattern, appreciating during the boom and falling abruptly during the crisis. Although the solvency ratio deteriorated over the course of each cycle, BoP crises only occurred after large declines in the liquidity ratio. That happened in the 1970s and the 1990s. The elasticities of exports and imports with respect to the RER did not affect this pattern very much, and the main current-account effect of devaluations occurred through contraction of imports owing to lower income growth (Amico and Fiorito 2017). In the 1990s, the combination of open financial markets and a fixed-peg exchange-rate system induced strong short-term speculative investment inflows. In the 2000s cycle there was no deterioration in the liquidity ratio among developing countries, independent of what happened to the RER (strong appreciation in Brazil generated by a high interest rate, and much weaker appreciation in Argentina due to its exclusion from the financial market). In other words, the exchange-rate regime (defined as control of capital inflows, freedom to float the nominal exchange rate, and the composition of capital inflows in terms of short-term credit or other financial inflows) seems have been far more significant for the BoP crisis than the behavior of the RER.

In contrast to the above arguments emphasizing financial factors and the exchangerate regime, ND focuses only on the absolute level of the real exchange rate. According to ND, overvaluation is the primary cause of external crisis, and speculation and financial factors play a secondary role which only acts on the real economy via their effect on the real exchange rate (see Frenkel and Rapetti 2014). 


\section{INDUSTRIALIZATION AND EXPORT DIVERSIFICATION DEMAND A MULTITUDE OF INSTRUMENTS}

A broad message from $\mathrm{CD}$ is that cumulative causation, associated with technical progress and financial power, generates crucial advantages for hegemonic countries. Consequently, for latecomers the diffusion of modern industries requires new strategies. Their success depends on their adequacy relative to the level of a country's economic backwardness and political or geopolitical possibilities. In successful experiences of catch-up, low wages have not been a strategic asset to compensate for much lower productivity.

In the nineteenth century, when Great Britain exerted its hegemony through the imposition of global free trade, industrialization in the rest of the world required trade protection and industrial policies to compensate for Britain's technological, trade, and financial superiority. John Stuart Mill's (1848 [1968]) argument on infant-industry tariff protection became dominant among economists, but it was neither the most important nor a sufficient industrial policy for latecomers. Alexander Hamilton (1827 [2007]) and Friedrich List (1837 [1983]) considered many other policies. According to Ho (2010), both Hamilton and List considered a protective tariff was necessary to reduce the huge differences of cost, but they also thought it insufficient to unleash a latecomer country's productive power to compete with technological leadership. Nor was a tariff the most important policy. In addition to tariffs and subsidies, effective government efforts on infrastructure, finance, and science and technology were all central for late industrialization. If there are strong externalities within the economic system, the low level of productivity in a particular new industry in a latecomer country is not just the result of the industry's immaturity, but is also due to the low level of the efficiency of the overall economy.

Tariffs, subsidies, and the exchange rate can protect and stimulate manufacturing investment for internal or export markets but they are not a sufficient tool for industrialization and economic growth. Tariffs and subsidies change the prices of particular branches of the economy, altering their profitability. The exchange rate changes the profitability and labor cost of all tradable goods. The effect on economic growth depends on what happens with final demand, productivity, and competitiveness. Arguably, most controversial is the role played by the exchange rate on economic growth due to its direct effect on income distribution and its blunt nature, subsidizing all exports irrespective of their importance for technological evolution.

As regards price competitiveness in a fixed exchange regime, increases in nominal wages above productivity increases negatively affect manufacturing's price competitiveness. This is particularly relevant for light industries (or in labor-intensive activities in modern chains led by transnational corporations) where labor costs are important. In a flexible exchange regime, exchange-rate devaluation can restore price competitiveness by lowering labor costs expressed in international terms. Nevertheless, unless subsidies or investments in wage goods keep their prices constant, that increase in competitiveness always occurs through a lower real wage. ${ }^{7}$

Developing countries confront two different roads to improve manufacturing export performance. The first is cutting wages directly or through exchange-rate

7. On this, see for example Shaikh (2016, p. 533): '[C]urrency devaluation will not, in itself, eliminate trade deficits. Rather, it would be successful only to the extent that it affects the real unit costs (via the real wage) and/or the nontradable-tradable price ratio of consumer goods ... and that depends on the ability of workers and consumers to resist such effects.' 
depreciation - the low road. The second is increasing productivity, not only in manufacturing exports, but also in the production of wage goods and changing specialization towards new goods and activities with higher demand - the high road. As Amsden (2001, p. 6) argues, the advantage of the first method is that it is automatic, but she warned that 'wage cuts are no guarantee that either skills will rise or total cost will fall sufficiently.' Also, there is no guarantee that a higher export rate would compensate for lower consumption in domestic goods. As observed in the most successful developing economies, the evolution of real wage has been a significant source of manufacture demand. The low road to external competitiveness, typically represented by export processing zones, was present in all Asian countries at the beginning of their take-off. However, in most successful export countries it was replaced by the high-road approach, implemented through multiple instruments. ${ }^{8}$

In the Classical, Institutionalist, and Keynesian literature on development the role played by price and exchange-rate competitiveness for economic growth and technical change was subsidiary. Bresser-Pereira (2016, p. 339) considers that the 'preference' for quantities rather than prices is a misconception of $\mathrm{CD}$ because 'prices remain the crucial coordinating tool of the economic system.' However, earlier authors were quite skeptical about the price elasticity of exports and imports and, thus, about the effects of the exchange rate on growth. Given the fact that the economic system is circular, a price change between tradable and non-tradable goods (that is, an internal devaluation) can lead to a rise in the costs of inputs of non-tradable goods absent other compensating exchange-rate policies. The net result therefore depends on a set of interactions and distributive conflict (Amico and Fiorito 2017).

Prebisch, particularly, was concerned with the inflation and distributive effect of exchange-rate devaluations. All these earlier authors considered investment in infrastructure, tariffs, subsidies, and capital controls far more relevant for competitiveness and structural change than the exchange rate. Classical Developmentalist and Keynesian skepticism on price competitiveness includes the argument that even if the price elasticities satisfy the Marshall-Lerner conditions, the exchange rate is a limited instrument given its effect on the level of prices, real wages, and aggregate demand (López and Perrotini 2006).

Kaldor (1978a), who seems to be a leading reference for the ND conception of industrialization, had a nuanced position when he discussed the role played by exchange rate on competitiveness (Targetti 1992). He observed that RER competitiveness was not the cause but the consequence of different market shares, which are explained by technological factors. He also considered the negative distributive effect of exchange-rate depreciation. According to Targetti (ibid., p. 323),

although the instrument of exchange rate adjustment reduces a country's wages level relative to its competitors, it acts on the average value of labor costs per unit of output. A fall in the exchange rate - at a given level of money-wages - has the same effect as a general reduction of real wages. Hence a policy designed to improve competitiveness through devaluation is limited by the extent to which wage-earners will accept a reduction in their real wages.

8. As observed by Shaikh (2016, p. 533), 'the classical approach allows us to distinguish between two basic routes to increasing a country's international competitiveness: (1) the high road that operates by continuously improving productivity; and (2) the low road that seeks to depress real wages and shift the burden of adjustment onto the backs of workers. The key point here is that rising productivity is compatible with rising real wages ... .' 
Additionally, if external demand is not increasing, depreciation of the exchange rate only increases the country's competitiveness if the exchange rates of the trading partners remain constant, otherwise a kind of 'beggar thy neighbor' effect occurs. That undermines efforts to gain competitiveness through the exchange rate and initiates an immiserating growth process or a race to the bottom, in which wages fall for all involved.

As noted by López and Perrotini (2006), Kaldor (1978b, pp. 49-50) discussed the effects of exchange-rate depreciation as follows: 'the correct amount of devaluation ... presupposes strongly deflationary internal policies while the process of structural adjustment is going on, as well as a succession of downward adjustments in the exchange rate, and not a single, once-for-all adjustment.'

The reason, comment Lopez and Perrotini (2006, p. 227), is that

the acquisition of a larger market share and the adaptation of the internal production structure favour of 'international goods' [takes time] and the exchange rate that may be necessary to attain the 'target' would represent an 'excessive adjustment'... . The economy could not respond to the change in relative prices, which would consequently be largely nullified by inflation.

One can imagine, in the current time and led by China's labor costs, how excessive the RER adjustment in developing countries would be.

Karshenas (2007) and Barbosa et al. (2013) connect the level of exchange rate with higher growth through the hypothesis that devaluation can encourage new manufacturing exports, increasing the rate of growth compatible with the external constraint. ${ }^{9}$ Such diversification and enlargement of the country's export basis has a once-andfor-all effect, but its positive influence on the rate of export growth depends on it changing the composition of exports toward goods with higher income elasticity. The model seems to consider that there are high-tech goods that can be exported by domestic firms if and only if the level of exchange rate is adequate. That is the same hypothesis followed in Bresser-Pereira's (2016) analysis. However, it is very difficult to see how this hypothesis holds when the country's challenge is to export goods and services with a higher value added and technological content and for which price competitiveness is not the dominant restraint. Krugman and Taylor (1978) view diversification of exports as the main factor needed to sustain a high level of exports, but they consider price competition through exchange rate contractionary. Lall (2003) and Freeman (2005) emphasize technical progress as the main driver.

If the real exchange rate has a limited impact on export growth, then the only other channel through which it could affect economic growth is if Marglin and Bhaduri's (1990) 'profit-led' growth regime is dominant (Pariboni 2015). This hypothesis holds that a depreciated exchange rate leads to relatively low unit labor costs (ULCs), which then promote investment in tradable goods (Frenkel 2008; BresserPereira 2016). If this hypothesis does not hold, and there is no credible evidence in that direction (López and Perrotini 2006; Fiorito et al. 2014), the exchange rate plays no predictable and direct role in determining the overall rate of GDP growth.

Despite the above difficulties, the connections between the level of exchange rate and economic structure play a crucial role for Dutch Disease theories considered by Structuralist authors such as Celso Furtado (1957) and Marcelo Diamand (1972).

9. For Karshenas (2007, p. 145) the 'way devaluations lead to improved export performance is not mainly through increased quantities of the same exports through price reductions but rather through a greater variety of products becoming more profitable to export.' 
Diamand (1972) examined the dynamics of economies such as Argentina and other Latin American countries during the import substitution period. Those countries suffered from an 'unbalanced economic structure' in which the primary export sector is internationally competitive whereas the industrial sector is not. The level of exchange rate reflected the higher productivity of primary exports. That structure did not prevent import substitution under protectionist tariffs, but it was a drawback for light manufacturing exports. Devaluations tend to immediately pass through to consumer prices, increasing distributive conflict and resulting in higher inflation and restoration of overvaluation. This unbalanced economic structure, typical of early Latin American Structuralist analysis, demanded many types of industrial policies to be corrected. ${ }^{10}$ Diamand considered that a comprehensive development policy, including tax on commodities prices and policies to increase the productivity in the wage-goods sector, was necessary to correct the structural imbalances. Investment in infrastructure and many types of industrial policy instruments must be in place to increase productivity and enable diversification of the structure of production and exports. Kaldor (1978b) defended a dual exchange rate, or a system of taxes and subsidies to simultaneously address the trade deficit and structural inflation problems (Targetti 1992).

As was argued in Section 1, Bresser-Pereira (2016) generalizes this analysis, with the tendency towards chronic overvaluation being conceptualized as a market failure. ${ }^{11}$ He correctly argues that the introduction of a tax on commodities can eliminate this imbalance but, differently from early Developmentalism, he disregards the negative effects of RER devaluation on income distribution. ${ }^{12}$

As noted earlier, none of his 70 propositions summarizing ND's approach (BresserPereira 2016, p. 342) deal directly with technical progress or infrastructure, and there is only one reference to technology: 'the exchange rate is overvalued in the long-term, the business enterprises that use state of the art technology are disconnected from effective demand.' That position seems to reflect orthodox thinking, which has been criticized by Lall (2003, p. 283), whereby firms in middle-income economies are assumed to 'operate with full knowledge of all technologies: they are on an universal, well-specified and well-behaved production function. Given the right market prices for inputs and outputs, they pick the technologies appropriate to national factor endowments.' From this orthodox perspective, the acquisition of technological capabilities does not require public investment, industrial policy, and adapting institutions. The only problem is the wrong price.

10. Furtado (1957) observed this same point regarding the Venezuelan experience (Medeiros 2008b). He considered that, in order to eliminate the contradiction of abundance of dollars and underdevelopment that resulted in RER appreciation, a comprehensive development strategy was necessary including industrial policies, agriculture modernization, autonomous public investment in infrastructure, and income distribution policies.

11. This hypothesis seems to consider, as in canonical Heckscher-Ohlin-Samuelson trade theory, that there is no technological gap, and the terms of trade fall when a nation has a deficit, but in Dutch Disease countries the exchange rate instead of expressing manufacture labor cost expresses the higher competitiveness of natural-resources exports. Consequently, this wrong price for manufacture, this 'imperfection,' is not automatically corrected by the market. For a critique of this standard assumption on exchange-rate adjustments, see Shaikh (2016).

12. Bresser-Pereira (2016) disregards the contractionary effect after RER devaluation and considers the conflict between exchange rate and real wage as being limited to the short run. In addition, he considers that the effect on inequality is limited, since only the rate of profit will increase. 
The central issue examined by Prebisch (1949) and Singer (1949) was the deterioration of the terms of trade and the resulting limits to growth. Peripheral countries specialize in the export of primary goods whose prices tended to decline in relation to industrial goods which are imported from the central countries. Industrialization was a necessary response of the peripheral countries to break with this underdeveloped (or bad) specialization that led to unstable growth, subordinated growth to external forces, and lowered GDP growth relative to industrialized countries.

ND fully assumes that perspective. However, two key circumstances have changed in recent decades. The first is the shift of global manufacturing to China, particularly as regards industry based on unskilled labor. The second is the rise in the price of primary commodities. Those two changes have in turn led to two important movements. The first was a reversal of the terms of trade between industrial goods and primary goods in a direction opposite to that observed and emphasized by Prebisch and Singer. The second was the creation within the manufacturing sector of the asymmetrical specialization previously observed between primary and industrial goods.

Thus, the reversal of terms of trade between industrial and primary goods is explained by the declining prices in manufacturing exported by developing countries, and particularly by Chinese exports of industrial goods. As observed in UNIDO (2017), the purchasing power of manufacturing exports (the value of manufacturing exports and the price of imports) has declined in countries that failed to upgrade the technological content of their manufacturing exports. Essentially, this evolution has created a new trend and a new stage of the Prebisch-Singer thesis in which the deterioration of the terms of trade occurs essentially within manufacturing production. ${ }^{13}$ This modified Prebisch-Singer thesis and the commodification of manufactured goods is fully discussed in UNIDO (2017, p. 90) and deserves quotation:

The modified hypothesis starts from the observation that developing and emerging industrial economies differ from industrialized economies in their technological capacity, institutional settings, labour markets and so on. Their manufacturing products therefore tend not to be technology intensive but labour intensive and easily imitated by other market entrants. This competition through entry puts downward pressure on global prices for manufactures, limiting the income-generation potential of foreign demand. In addition, embodied technical change through imported capital goods tends to decrease, rather than increase, prices. Under these conditions, an industrialization strategy designed to tap into global demand for manufactured products will not contribute to promoting wealth domestically.

ND neglects that, in this new world division of labor (already observed by Singer and Ansari 1977), developing countries need to change their trade specialization through industrial innovation and product diversification (not limited to price competition) in order to achieve successful industrialization.

Developmental efforts must change as the economy evolves. The diffusion of new information and communications technologies (ICT) and the formation of global and regional production chains places new demands and requires changed national industrial policies. A second phase of catching up, based on innovation and the construction of proprietary national technologies, occurred in China, South Korea, and Taiwan (Chang 2006). Historically, mastering, improving, borrowing, and absorbing existing

13. 'A price-driven expansion of exports generates new incomes at home, where price effects can also have a positive impact on the disposable incomes of consumers. But the country will have to export more and more to import the same volume of commodities and services' (UNIDO 2017, p. 89). 
technologies were the main challenge for developing countries demanding adequate institutions. The acceleration of innovation, relocation, and growing control of technical progress by transnational corporations (TNCs) in global value chains (GVCs) increases the importance of national capabilities as a critical determinant for successful development and technological upgrading (Milberg and Winkler 2013).

Unlike the period 1950-1980, the 'neo-developmental' strategy of recent decades has targeted both markets for domestic manufacture and firms' technological upgrading and scale needed for global competition. The processes of productive regionalization and internationalization has expanded firms' investment horizons. China started its high growth through production and exports of light manufacture. That was followed by a new strategy that changed its structure and directed specialization toward high-tech activities. This strategy combined public investment in infrastructure - the main inducer of overall growth productivity - with selective industrial policy in ICT technologies. The focus of the new strategy is less centered on the manufacturing sector, as prevailed in the 1950-1980 period. Instead, it is based on innovation processes and activities in new technologies through several policies and instruments.

China, India, and a few other East Asian countries followed this 'high-road' route based on upgrading and modernizing industrial policies. However, in most developing countries, the Neoliberal reforms adopted in the 1990s simply dismantled the old strategy without replacing or updating it for the new circumstances. The crisis of the developmental state is synonymous with the crisis of the industrial policy.

In South America, the first decade of the twenty-first century was much better than the 1990s (when the Washington Consensus reforms were implemented) and brought higher investment and higher wages. However, there has been no progress regarding reconstructing the national state's developmental capabilities, restoring high levels of infrastructure investment, and increasing efforts for technological upgrading. That failure to relaunch a developmental strategy to cope with the new challenges occurred at the same time that the expansion of Chinese exports were lowering all industrial prices (due to China's scale, productivity, and low wages) regardless of their technological content. That 'China effect' led to an overall loss of competitiveness and industrial overvaluation in other countries.

Although ND recognizes the importance of industrial policy, such a policy seems to play a secondary role in its view of structural change and is deemed a mere side-show to a competitive RER. According to the ND perspective, Latin American economies have fallen behind Asian economies since 1980 not because of their misguided or passive industrial policy or because of the backwardness of their enterprise and economic systems. Instead, they fell behind because they failed to provide the competitive exchange rate required by their existent competitive industries. That view is rejected by a Structuralist-Institutionalist perspective.

\section{FINAL COMMENTS}

Although reflection on economic development emerged with the beginning of political economy in the eighteenth century, it was only in the post-WWII period (particularly the 1950s and 1960s) that development economics gained standing as a stand-alone field concerned with the development of backward economies. The 'Pioneers of Development' - such as Arthur Lewis, Rosestein-Rodan, Ragnar Nurkse, Hans Singer, and Raul Prebisch - explored the problems and challenges facing post-war developing countries which sought to change their economic and social environment in order to 
sustain higher growth and deliver better opportunities for their populations. The perspective of these authors is referred to as Classical Developmentalism. Economic development was identified with industrialization. In order to change and bring about new opportunities for developing countries, the traditional pattern of trade specialization had to change, and that required active industrial polices and structural change.

Since 2000 the initial debate on structural change has been superseded by a debate contrasting experience of East Asian and Latin America economies. This second debate centered on the huge disparity in economic performance of these two regions in the 1980s, and it has pitted World Bank and free-trade economists against Structuralists, Institutionalists, and other critical social scientists. World Bank economists attributed East Asia's development success to 'market friendly' state intervention, and they attributed Latin America's development failure to pervasive and distortionary state intervention. By contrast, Structuralist-Institutionalist economists argued that in East Asian economies (particularly those of Japan, South Korea, and Taiwan) the state did not stand aside but rather led the market via selective industrial policy. Those policies created new competitive advantages in productive sectors and activities that were very different from their factor endowment. This state leadership explicitly distorted prices, and investment was actively allocated in new areas through state banks and powerful planning agencies. The essence of the controversy in this second debate was not macroeconomics, but rather the role of industrial policy and activist investment allocation in promoting structural change. Many critical authors explored the role of National Innovation Systems (NIS) in achieving high external manufacture competitiveness. Despite the different historical context, this Institutionalist and Schumpeterian perspective contained several similarities with CD, with both emphasizing structural change and defending industrial policy as an essential mechanism of productive and technological development.

In the 1990s that second debate was supplemented by a third debate focused on global financial deregulation and financial capital mobility. This third debate created strong pressures for Neoliberal reforms which were unequally implemented in regions. Latin American countries enthusiastically adopted the Washington Consensus reforms. The result was a 'stop and go' pattern of growth characterized by increasing dependency on primary exports and capital inflows. Additionally, growth rates were disappointing, income distribution worsened, industrial modernization slowed, and there were also recurrent BoP crises. Many previously successful East and Southeast Asian economies also opened their capital accounts and they too experienced BoP crises. In contrast, China and Taiwan did not open their capital accounts and their overall performance was much better. In contrast with the second-round debate, the third-round debate emphasized macroeconomics, particularly the role of financial liberalization on economic growth. For Post-Keynesian economists, and economists in organizations such as ECLAC and UNCTAD, financial openness was the main cause of the volatile growth pattern and the proliferation of external crises in both Latin America and East Asia.

The rapid increase in commodity prices, its impact on the economic growth of primary exporting countries from 2003 until 2010, and the subsequent deceleration of commodity prices and of growth, has provided the context for the latest round of economic development controversies. In this latest round, heterodox economists following a Post-Keynesian perspective, and organizations such as ECLAC, have argued that the divide between successful (East Asian countries and China) and unsuccessful developing countries reflects differences in productive structure particularly as 
regards the competitiveness of the manufacturing export sector. However, a new divide has emerged within heterodox economic thinking regarding the significance of industrial policy and technical change versus macroeconomic policy. The new focus on macroeconomic policy is strongly associated with ND. It argues that increased financial liberalization and high prices of commodities contributed to an appreciated real exchange rate that retarded industrialization and growth. Additionally, it reinterprets history and argues East Asian catching-up was the outcome of a successful export-led growth strategy made possible by a competitive real exchange rate.

This paper has provided a critical assessment of ND as summarized in BresserPereira (2016). It argues that, although ND correctly observes that CD underestimated and insufficiently considered the role of demand as a motor of growth, ND theory now mistakenly attributes and explains changes in quantities (particularly external demand) to prices (particularly the exchange rate). As such, it shares much in common with conventional views of the economy in its suggestion that a particular market failure explains modern underdevelopment in middle-income countries. According to ND theory, inducing the structural changes necessary for higher economic growth requires that macroeconomic prices (particularly the exchange rate) must be right. That view contrasts with CD and modern Institutionalist and Schumpeterian thinking. For the latter economists, prices play an important role for distribution, resource allocation, and competitiveness. However, development and structural change require strategic policies that go far beyond macroeconomic prices.

Structural change requires a complex set of industrial policies, investment coordination, and developmental institutions that far exceed ND's focus on macroeconomic prices. The RER is important for competitiveness, particularly for light industries. However, it is of much less significance for competitiveness in sectors that require innovation, incorporation of technical progress, and industrial policies. Structural change and high levels of investment that occurred in East Asia (yesterday and today), and in some Latin America countries (yesterday but not today), were the product of multiple intervention mechanisms. Since the 1990s, industrial policy has ceased being important in Latin America, but it has been revamped in successful Asian economies.

\section{REFERENCES}

Amico, F. and F. Fiorito (2017), 'Inflación, crecimiento y balanza de pagos: el rol del tipo de cambio,' in F. Medici (ed.), Discusiones sobre el tipo de Cambio, Buenos Aires: Universidad Nacional de Moreno, pp. 39-84.

Amsden, A. (1989), Asia's Next Giant: South Korea and Late Industrialization, New York: Oxford University Press.

Amsden, A.H. (2001), The Rise of 'the Rest', New York: Oxford University Press.

Barbosa, N., M. Ferrari, and F. Freitas (2013), 'O papel da taxa de câmbio real nos modelos de restrição externa: uma proposta de releitura,' Brazilian Journal of Political Economy, 36, 919-939.

Bresser-Pereira, L.C. (2016), 'Reflecting on new developmentalism and classical developmentalism,' Review of Keynesian Economics, 4(3), 331-352.

Cesaratto, S., F. Serrano, and A. Sirati (2003), 'Technical change, effective demand and employment,' Review of Political Economy, 26(2), 303-324.

Chang H.-J. (2006), The East Asian Development Experience: The Miracle, the Crisis and the Future, London: Zed Books. 
Diamand, M. (1972), 'La estructura productiva desequilibrada: Argentina y el tipo de cambio,' Desarrollo Económico, 12, 1-24.

Fiorito, A, N. Guaita, and S. Guaita (2014), 'Neodesarrolismo y el tipo de cambio competitivo,' Cuaderrnos de Economia, 34(64), 45-88.

Freeman, C. (2005), 'New technology and catching up,' in R. Kaplinsky and C. Cooper (eds), Technology and Development in the Third Industrial Revolution, London: Frank Cass, pp. 83-96.

Frenkel, R. (2008), 'Tipo de cambio real competitivo, inflación y política monetaria,' Revista de Economía Política de Buenos Aires, 2(3-4), 21-32.

Frenkel, R. and M. Rapetti (2014), 'The real exchange rate as a target of macroeconomic policy,' MPRA Paper 59335, University Library of Munich.

Furtado, C. (1957 [2008]), 'O Desenvolvimento Recente da Economia Venezuelana,' in C. Furtado, Ensaios sobre a Venezuela, Subdesenvolvimento com abundância de divisas, Rio de Janeiro: Contraponto, Centro Internacional Celso Furtado, pp. 35-118.

Gore, C. (1996), 'Methodological nationalism and the misunderstanding of East Asian industrialization,' European Journal of Development Research, 8(1), 77-122.

Hamilton, A. (1827 [2007]), Report on the Subject of Manufactures, New York: Cosimo Classics.

Hausmann, R. and C. Hidalgo (2010), 'Country diversification, product ubiquity and economic divergence,' Harvard University, CID Working Paper, No 201.

Ho, P. (2010), Rethinking Trade and Commercial Policy Theories, Cheltenham, UK and Northampton, MA: Edward Elgar Publishing

Kaldor, N. (1966), Causes of the Slow Rate of Economic Growth of the United Kingdom, New York: Cambridge University Press.

Kaldor, N. (1978a), 'The effects of devaluation on trade manufacture,' in N. Kaldor, Essays on Economic Policy, vol. 6, Collected Papers, London: Duckworth, pp. 99-116.

Kaldor, N. (1978b), Further Essays on Applied Economics, London: Duckworth.

Karshenas, M. (2007), 'Real exchange rates, labor markets, and manufacturing exports in a global perspective,' in A. Shaikh (ed.), Globalization and the Myth of Free Trade, New York: Routledge, pp. 139-173.

Krugman, P. and L. Taylor (1978), 'Contractionary effects of devaluation,' Journal of International Economics, 8(3), 445-456.

Lall, S. (2003), 'Technology and industrial development in the era of globalization,' in H.-J. Chang (ed.), Rethinking Development Economics, London: Anthem Press, pp. 277-298.

List, F. (1837 [1983]), The Natural System of Political Economy, London: Frank Cass.

López, J. and I. Perrotini (2006), 'On floating exchange rates, currency depreciation and effective demand,' BNL Quarterly Review, LIX(238), 221-242.

Marglin, S. and A. Bhaduri (1990), 'Profit squeeze and Keynesian theory,' in S. Marglin and J. Schor (eds), The Golden Age of Capitalism: Reinterpreting the Post War Experience, Oxford: Clarendon, pp. 153-186.

Mazzucato, M. (2013), The Entrepeneurial State: Debunking Public vs. Private Sector Myths, London, New York and New Delhi: Anthem Press.

Medeiros, C.A. (2008a), 'Financial dependency and growth cycles in Latin America countries,' Journal of Post Keynesian Economics, 31, 79-100.

Medeiros, C.A. (2008b), 'Celso Furtado na Venezuela,' in R. Freire d'Aguiar Furtado (ed.), Ensaios sobre a Venezuela, Subdesenvolvimento com abundância de divisas, Rio de Janeiro: Contraponto, Centro Internacional Celso Furtado, pp. 137-156.

Medeiros, C.A. (2017), 'Industrialization, trade and economic growth,' in M. Vernengo (ed.), Why Latin American Nations Fail, Berkeley, CA: University of California Press, pp. 17-38.

Medeiros, C.A. and F. Serrano (2004), 'Desenvolvimento Econômico e Abordagem Clássica do Excedente,' Revista de Economia Política, 24(2), 238-257.

Milberg, W. and D. Winkler (2013), Outsourcing Economics, Global Value Chains in Capitalist Development, New York: Cambridge University Press. 
Mill, J.S. (1848 [1968]), Principles of Political Economy, with Some of Their Applications from Social Philosophy, in Collected Works of John Stuart Mill, Vol. 3, London: Routledge \& Kegan Paul.

Palley, T. (2012), 'The rise and fall of export-led growth,' Levy Economics Institute, Working Paper 675. (Reprinted in Investigacion Economica, LXX(280), 15-35.)

Pariboni, R. (2015), 'Autonomous demand and the Marglin-Bhaduri model: a critical note,' Universitadi Siena, Quaderni del Dipartimentodi Economia Politica e Statistica, No 715.

Prebisch, R. (1949), 'El desarrollo económico de América Latina y sus principales problemas,' E/CN 12/89, Santiago do Chile, CEPAL.

Rodrik, D. (2004), 'Industrial policy for the twenty-first century,' Paper prepared for UNIDO.

Shaikh, A. (2016), Capitalism, Competition, Conflict, Crises, New York: Oxford University Press.

Singer, H.W. (1949), 'Economic progress in underdeveloped countries,' Social Research: An International Quarterly of Political and Social Science, 16(1), 1-11.

Singer, H.W. and J.A. Ansari (1977), Rich and Poor Countries, London: Allen \& Unwin.

Targetti, F. (1992), Nicholas Kaldor: The Economics and Politics of Capitalism as a Dynamic System, London: Clarendon Press.

Thirlwall, A.P. (1979), 'The balance of payment constraints as an explanation of international growth rates,' Banca Nazionale del Lavoro Quarterly Review, 128, 45-53.

UNIDO (2017), Industrial Development Report, Geneva: United Nations.

Wade, R. (1990), Governing the Market: Economic Theory and the Role of the Government in East Asia Industrialization, Princeton, NJ: Princeton University Press. 